\title{
Legal Analysis of Hospital Dispute Settlement through Mediation by Provincial Hospital Supervisory Board (BPRS)
}

\author{
Nurani Ajeng Tri Utami ${ }^{1 *}$ \\ ${ }^{1}$ Faculty of Law, Jenderal Soedirman University, 53122, Purwokerto, Indonesia
}

\begin{abstract}
Law No. 44 year 2009 on Hospitals mandates the establishment of the Hospital Supervisory Board (BPRS) at national and provincial levels. One of the duties of the Provincial Hospital Board of Supervisors, as mentioned in Article 60, is to receive complaints and to mediate the dispute resolution process. Previously, if the parties agree to use the settlement of the dispute with mediation, it only involves the hospital with the patient or the party who feels aggrieved, and the mediator if necessary. However, there are still hospitals or parties who are harmed by the hospital who directly sued to the court. This paper will explain normatively how the arrangements and obstacles on the dispute settlement of the hospital by means of mediation through BPRS. This research uses normative juridical method with statute approach and analytical approach. The result of this research will describe the arrangement comprehensively and constraint normatively about BPRS as a scientific information for the improvement of BPRS.
\end{abstract}

\section{Introduction and Literature Review}

The relationship between patients and health workers in hospitals is within the scope of the agreement law. Legal relations between hospitals/doctors and patients originating from agreements occur due to their agreement. The agreement between the hospital/doctor and patient is called a therapeutic agreement [1]. As an agreement, rights and obligations arise as a result of the agreement [2]. The principal agreement that arises in the therapeutic agreement is the obligation of the doctor to make medical efforts and the patient's right to the medical effort, the patient's obligation to pay honorarium to the doctor for his medical efforts and the doctor's right to pay the honorarium [3]. The implementation of rights and obligations often results in disputes.

The trigger of disputes in hospitals is misunderstanding, differences in interpretation, unclear arrangements, dissatisfaction, offense, suspicion, inappropriate actions, cheating or dishonesty, abuse or injustice, and the occurrence of unforeseen circumstances [4]. Lately disputes between doctors and patients often occur, even from several conflicts involving hospitals as a health facility. The results of the study in Semarang, there were 20 cases of

\footnotetext{
* Corresponding author: nuraniajeng11@gmail.com
} 
patients suing the hospital (in private hospitals), 15 cases suing government hospitals and teaching hospitals [5].

Hospital disputes are not only related to medical personnel working in it, but can also relate to hospitals as legal entities, such as land disputes and environmental disputes. The Tiara Shella Bengkulu hospital gets environmental pollution lawsuit and has problems in extending the hospital operational permit [6]. The hospital as a place to work for health workers, will involve all types of health workers as specified in Article 11 (1) of Law No. 36 of 2014 concerning Health Workers, so that there is a working relationship between hospitals and health workers. This also means that medical personnel will also relate to other health workers in carrying out their profession in the hospital. In general, the agreement to do this work is regulated in Article $1601 \mathrm{BW}$ based on certain conditions by receiving wages. These conditions can be stated in the job description made by the hospital as a legal entity as the party giving the job and the health worker involved as the recipient of the job (werknemer).

Since October 28, 2009 Indonesia has Law No. 44 of 2009 concerning Hospitals. The Hospital Law governs the establishment of a Hospital Supervisory Agency at the national and provincial levels. One of the tasks of the Provincial Hospital Supervisory Board, as mentioned in Article 60 is to receive complaints and make a dispute resolution by mediation. Previously, if the parties agreed to use a dispute settlement by mediation, then it only involved the hospital with the patient or the party who felt aggrieved, and the mediator if needed. However, there are still hospitals or parties who have been harmed by the hospital who immediately sued the court. After the Hospital Law, the hospital must seek the settlement of disputes through mediation and submitted to the Provincial Hospital Supervisory Board, so that it is expected that hospital disputes do not need to go to court.

\section{Objectives of the Study}

This paper will explain how to manage hospital dispute resolution by means of mediation through the Provincial BPRS and also what are the normative barriers to the organization of hospital dispute resolution by means of mediation through the Provincial BPRS.

\section{Methodology}

The problem approaches used in this research are the statute approach, analytical approach, and conceptual approach. The legislation approach will be used to address the problem of setting hospital dispute resolution by means of mediation through the Provincial BPRS. Hospital dispute settlement arrangements will be carried out by inventorying laws and regulations related to BPRS and Hospitals. Analytical and conceptual approaches are used to resolve problems regarding normative barriers to the arrangements of hospital dispute settlement with mediation through Provincial BPRS.

\section{Discussion}

\subsection{Arrangement of hospital dispute settlement by means of mediation through the Provincial BPRS}

Since the existence of Law No. 44 of 2009 concerning hospitals, the government and regional governments carry out guidance and supervision of hospitals by involving professional organizations, hospital associations, and other social organizations in accordance with their respective duties and functions. Development and supervision of non-technical hospitals are 
carried out internally and externally. These are internally carried out by the Hospital Supervisory Board and externally carried out by the Hospital Supervisory Board.

The number of disputes that occur in the hospital or involve the hospital requires an agency in charge or authorized to resolve the dispute. So a rule was established as its legal umbrella, namely Goverment Regulation (PP) No. 49 of 2013 concerning the Hospital Supervisory Board. Based on the PP, the BPRS is divided into two, namely the Indonesian $B P R S$ and the Provincial BPRS. Based on Article 24 of Government Regulation No. 49 of 2013 concerning BPRS, it states that one of the tasks of the Provincial BPRS is to follow up on complaints in order to resolve disputes through mediation.

In general, a dispute resolution can be used in two ways, namely litigation (court) and non-litigation / consensual / non-adjudication. We can all understand that court proceedings are a costly and time consuming process. Because the conventional court system is naturally opposite, it often results in one party being the winner and the other as the losing party. Meanwhile, sharp criticism of the judiciary in carrying out its functions is considered too dense, slow and time-consuming, expensive and less responsive to public interests and considered too formalistic and too technical. That is why the problem of reviewing the improvement of the justice system in an effective and efficient direction is everywhere. Even criticism emerged saying that the civil process was considered inefficient and unfair (civil procedure was neither efficient no fair).

Based on the above, an idea emerged to resolve the dispute over alleged malpractice in a win solution, one of which was mediation [7]. The mediation process is one form of Alternative Dispute Resolution (ADR) or alternative problem solving. With the enactment of the Supreme Court Regulation of the Republic of Indonesia (PERMA) Number 1 of 2016 concerning mediation procedures in court, there have been fundamental changes in the practice of justice in Indonesia. The court is not only tasked and authorized to examine, hear and resolve the cases received, but also has the obligation to seek peace between the litigants. The court, which has always been law enforcement and justice institution, has now appeared as an institution that seeks a peaceful solution between the warring parties [8].

Based on the authority possessed, the Provincial BPRS supervises the receipt and handling of complaints by:

a. ask the hospital to fill out an independent and coping secret report online on the BPRS official website;

b. request annual reports of the Hospital Supervisory Board online every year which includes reports on receipt and handling of complaints;

c. request report of the unit of community complaints service (UPPM) on provincial level;

d. make a direct visit to the hospital, there is a complaint directly to the Provisional BPRS;

e. report on the results of complaints by the Provincial BPRS to the Indonesian BPRS and coordinate with other supervisory institutions.

Based on Article 39 PP No. 49 of 2013, it was settled in a hospital by a provincial BPRS carried out in consultation. This was evidenced by the decision made by the Provincial BPRS at a meeting attended by all members. In addition, you can invite others to find input and suggestions in accordance with the meeting material. In the case of consensus not to reach consensus, it can be carried out by voting based on the most votes.

Based on the Decree of the Chairperson of the Indonesian Hospital Supervisory Agency Number HK.02.04 / III.8 / 066/2016 Concerning the Procedure for Complaint Handling by the Provincial Hospital Supervisory Board used by the BPRS consists of three stages.

1. Stage of administering public complaints

At this time is recording, reviewing, channelling and filing.

2. Process stage for proving public complaints

At this stage confirmation and clarification, research / examination and reporting of the results of the examination are carried out. 
3. Follow-up stage and monitor public complaints

At this stage there is a form of no further research / examination results, utilization of the results of public complaints handling, monitoring and coordination of follow-up on community complaints handling, and sanctions recommendations.

The flow of complaints against hospital disputes can be done in various ways, namely:

1. Complaints from the public directly to the hospital

The flow of complaints and the handling of disputes in this pathway consist of several stages, namely:

a. The community submits the complaints to the hospital

b. The hospital resolves disputes with mediation

c. Disputes are resolved by means of hospitals that report to provincial BPRS or if not completed, the provincial BPRS can proceed to mediate.

d. Provincial BPRS reports the results of mediation to Indonesian BPRS.

2. Public Complaints to Provincial BPRS

The flow of complaints and the handling of disputes in this pathway consist of several stages, namely:

a. Community and / or hospital submit a complaint to the Provincial BPRS

b. The Provincial BPRS calls the complainants and complains in order to resolve disputes through mediation; the Provincial BPRS is coordinated with the Hospital Oversight Board and the Provincial Health Office.

c. Provincial BPRS reports the results of mediation to Indonesian BPRS

d. If the provincial BPRS has not been settled, the dispute resolution through mediation is carried out by the Provincial Health Office.

In resolving disputes in hospitals by the Provincial BPRS through mediation must be based on the principles of objectivity, coordination, effectiveness and efficiency, accountability, confidentiality, transparency, Presumtion of Innosence (principle of presumption of innocence), and all activities are always accompanied by written documents so that decisions will be obtained mediation which is a win solution for the parties to the dispute.

\subsection{Normative Obstacle to solving hospital problems by mediating through provincial BPRS}

Based on the regulations governing the BPRS, especially the resolution of disputes conducted by means of mediation shows that there are some normative obstacles. This can be described as below:

1. In terms of its formation, in Government Regulation No. 49 of 2013 Article 22 states that the establishment of a Provincial BPRS "can" be carried out based on the provisions of the Governor. The word "can" seems not obligatory for all Provinces to form Provincial BPRS. This has resulted in a non-uniformity of BPRS in each province, although the $P P$ has not yet established a provincial BPRS that can be accessed by the Provincial Health Office with mediation.

2. According to an institutional point of view or the establishment of an Provincial BPRS, Article 23 PP No 49 of 2013 states that it is still under the Provincial Health Service which is responsible to the governor. This raises the concept that the provincial BPRS is not yet fully independent.

3. In terms of the decision that is in accordance with Article 24 and 25, this goverment regulation can be made from the decision of the completion of the hospital which is prepared by the Provincial BPRS only in recommendation. So the final decision is given to the governor or the Provincial Health Office. It can be indicated that the decision of the mediation of the Provincial BPRS does not have executorial rights. 
4. The mediation process or procedure seen in the decision of the Chairperson of the Indonesian Hospital Supervisory Agency Number HK.02.04 / III.8 / 066/2016 concerning Procedures for Complaint Handling by the Provincial Hospital Supervisory Board does not explain the mediation process in detail; the type of dispute, time period, or mediator and the conditions. Referring to Supreme Court Regulation of the Republic of Indonesia No 1 of 2016 concerning mediation procedures in the Court, the differences are very visible, especially the use of certified mediators. In the Decree of the Head of the BPRS, mediation is used which looks like a consensus deliberation between the disputing party and the BPRS as the mediator / mediator.

\section{Conclusion}

The arrangements of hospital dispute settlement by the Provincial Hospital Supervisory Agency have been accommodated in various regulations including the Law No. 44 of 2009 concerning Hospitals, PP No. 49 of 2013 concerning BPRS, Regulation of the Minister of Health No. 88 of 2015, and Decree of the Chairperson of the Indonesian Hospital Supervisory Agency Number HK.02.04 / III.8 / 066/2016. From the various regulations, it can be seen that the mediation process is carried out by the Provincial BPRS by way of deliberation with two complaints channels, namely through the hospital or through the Provincial BPRS itself where later the result is a recommendation that will be submitted to the Governor or the Provincial Health Office in the event of a final decision. The normative obstacle to dispute resolution arrangements through mediation by the Provincial BPRS is seen in terms of formation, institutions owned by the Provincial BPRS, mediation decisions produced, and also the procedures which are not explained in detail.

\section{References}

1. F. Mufidi, S. Pursetyowati, Jurnal Ilmu Hukum Wacana Paramarta, Vol. 8 No. 1 Edisi Bandung: Fakultas Hukum Universitas Langlangbuana 23 (2009)

2. Nuryanto, Jurisprudence, 1, 1. Pp.2, (2012)

3. B. Sukarjono, Sosial, 10, 2 , Pp.33 (2009)

4. D. Afandi, eJKI, 59, Pp. 189, (2009)

5. E. K. Astuti. JMMH, 40, 2, Pp. 163-171 (2011)

6. Radar Bengkulu, Kasus RS Tiara Shella Juga Bergulir ke PTUN . (http://radarbengkulu.web.id/ published, Bengkulu, 2012).

7. A. Rahmat, Peranan Alternative Dispute Resolution dalam Penyelesaian Perkara Perdata (Padang Today. Padang, 2006)

8. Siddiki. Mediasi di Pengadilan dan Asas Peradilan Sederhana, Cepat, dan Biaya Ringan.(Telaga Ilmu Indonesia, Jakarta, 2009) 